Original Research Article

\title{
Ethnic differences in allele, genotype distributions and lung cancer risk of polymorphisms of gemcitabine metabolic pathway genes in south Indian population
}

\author{
Devika Tirumalasetty $^{1}$, Deepak Gopal Shewade ${ }^{1 *}$, Biswajit Dubashi ${ }^{2}$, Srinivasa Rao Katiboina ${ }^{3}$
}

\begin{abstract}
${ }^{1}$ Department of Pharmacology,
${ }^{2}$ Department of Medical

Oncology, Jawaharlal Institute of Postgraduate Medical

Education \& Research (JIPMER), Pondicherry, India

${ }^{3}$ Department of Pharmacology,

Sri Shankaracharya Institute of

Medical Sciences, Bhilai,

Chattisgarh 490020, India
\end{abstract}

Received: 05 August 2018

Accepted: 10 August 2018

\section{*Correspondence to:}

Dr. Deepak Gopal Shewade,

Email: dgshewade@gmail.com

Copyright: (C) the author(s), publisher and licensee Medip Academy. This is an openaccess article distributed under the terms of the Creative Commons Attribution NonCommercial License, which permits unrestricted noncommercial use, distribution, and reproduction in any medium, provided the original work is properly cited.

\begin{abstract}
Background: Gemcitabine is a widely used cytotoxic drug in the treatment of a number of solid tumors, for instance, lung, pancreatic as well as breast cancer. As a consequence of the progressive genomic instability, the efficiency rates have eventually lowered. Genetic approach targeting one or several genes in drug targeting pathways facilitates substantially more valuable details in explaining the association between variants and also the efficacy of gemcitabine therapy. In addition, several researchers have reported ethnic discrepancies in clinical response to gemcitabine. Thus, the present study was aimed to establish the normative frequencies of genes associated with the metabolic pathway of Gemcitabine (RRM1 -37C>A (rs12806698), RRM1 -524T>C (rs11030918), CDA 79A $>C$ (rs2072671) and CDA 435 C $>$ T (rs1048977) in South Indian healthy population and compared with 1000 genome population. Additionally, the association of these SNPs with the risk of developing lung cancer was also evaluated.

Methods: This study was carried out on 184 healthy subjects and 123 lung cancer patients of South Indian origin and genotyping was done using RT-PCR (Real Time Polymerase Chain Reaction). The frequencies of the above polymorphisms were in Hardy-Weinberg equilibrium ( $p>0$.05).

Results: The minor allele frequencies of the SNPs RRM1 -37C>A (rs12806698), RRM1 -524T>C (rs11030918), CDA 79A >C (rs2072671) and CDA -435 C>T (rs1048977) were 31.3, 36.7, 24.5 and 22.0 respectively.

Conclusions: There was a significant difference observed between the genotype and allele frequencies of south Indians with the 1000 genome populations. We also found that SNPs of RRM1 were significantly associated with lung cancer risk.
\end{abstract}

Keywords: CDA, Ethnic, Gemcitabine, Lung cancer risk, Polymorphisms, RRM1

\section{INTRODUCTION}

Lung cancer is amongst the most common cancer problems across the globe. Cytotoxic gemcitabine combination chemotherapy is extensively employed for the management of metastatic lung carcinoma. As emphasized by GLOBOCAN, it has been determined that there were 1.8 million new lung cancer patients in 2012
(12.9\% of the overall total) of these, $58 \%$ eventuated in minimal evolved places. ${ }^{1}$ Around $85 \%$ of lung cancers are Non-Small Cell Lung Cancer (NSCLC) furthermore nearly all of the individuals manifest with metastatic stage, rendering it complicated in choosing the alternate restorative possible choices such as surgical and/or radiation procedures. Chemotherapy continues as the crucial part of conventional and also supportive health care 
in the majority of patients. ${ }^{2}$ Gemcitabine coupled with Carboplatin is one among the first - line regimens in later stages of NSCLC. This deoxycytidine analog is commonly used for treating, pancreatic, lung and breast malignant tumors alone or along with other drugs. ${ }^{3,4}$ Gemcitabine and carboplatin regimen provides substantial efficacy $(29.6 \%$ vs $11.3 \%$ ) combined with enhanced outcomes in terms of overall survival (2-year survival rate $15 \%$ vs $5 \%$ ) in contrast to single drug therapy having more with treatable hematological toxicities. ${ }^{5}$ Even though it continues to be main regimen for many malignancies, there exists interindividual variations with regard to efficacy of the drug. Literature shows that the variants in the metabolic pathway have been involved in hindering the expected clinical outcomes. The foundation of personalized chemotherapy that is based on these variations in genes which play a critical role in the pharmacokinetic and dynamic pathways can address the problems of resistance. ${ }^{6,7}$ Genetic polymorphisms in gemcitabine metabolic pathway can decrease response or resistance. ${ }^{5,8}$ Gemcitabine is a prodrug that needs cellular uptake and activation by phosphorylation. The key enzymes involved in the metabolism and response are $\mathrm{dCK}$ (deoxy Cytidine Kinase), CDA (Cytidine Deaminase) and RRM1(Ribonucleotide Reductase M1). The potent active metabolite dFdCTP (diFluoro deoxyCytidine TriPhosphate) gets incorporated into the DNA, which is followed by the addition of one or more deoxynucleotides, after which DNA polymerization stops leading to "masked chain termination". ${ }^{8,9}$ Mutations in CDA 79A>C was found to have a $21 \%$ lower clearance of gemcitabine as compared to patients with wild type CDA, and this resulted in severe hematologic toxicities. ${ }^{9}$ It was also reported that CDA A79A/A79C genotypes in 65 advanced NSCLC patients treated with cisplatin and gemcitabine had a significant positive correlation with clinical benefit, longer time to progression (TtP) and overall survival (OS). Moreover, CDA A79A was associated with grade 3 neutropenia/thrombocytopenia. A synonymous variant CDA 435C $>$ T (Thr145Thr) was associated with lower response rates and shorter TtP (Time to Progression) in
Asian lung cancer patients receiving carboplatin/gemcitabine. ${ }^{10,11}$ Increased RRM1 expression resulted in resistance to gemcitabine both in vitro and clinically. RRM1 promoter was analyzed and discovered that the two SNPs, 37C $>\mathrm{A}$ and $524 \mathrm{~T}>\mathrm{C}$ are in strong linkage disequilibrium. It was found that patients with the $37 \mathrm{CC} / 524 \mathrm{TT}$ allelotype had better overall and disease-free survival than patients with the 37AC/524CT allelotype. ${ }^{12,13}$ Similarly, the patients who received gemcitabine and carboplatin therapy showed a significant increase in over-all survival compared to other regimens. These patients showed significant lower expression levels of RRM1 implying the role of RRM1 in response to gemcitabine chemotherapy. This meta analysis also reports discrepancies that are observed in different studies regarding treatment selection based on the expression status of RRM1, ERCC1 that play a crucial role in cancer risk and clinical outcomes. ${ }^{14}$ Pharmacogenetics suggests that the SNPs of genes in gemcitabine metabolic pathway could be used as predictive markers for inter-ethnic as well as inter-patient outcomes. ${ }^{15}$

Ethnic variations have a significant role in the benefit of therapy with anticancer agents. ${ }^{16}$ India is a place with a large population comprised of a mixture of ethnic groups. Consequently, differences at genome level are natural among numerous groups, in addition to that Southern region marks a diverse group. ${ }^{17}$ These diversities might confound association outcomes and are the principal possibilities for the inconsistent results. ${ }^{18}$

Ethnic together with typical genetic markers are hence used as diagnostic and furthermore curative resources to achieve the purpose of personalized chemotherapy. In this study, we aim to establish the normative frequency of four SNPs of genes involved in metabolic pathway of gemcitabine, viz, (RRM1 -37C>A (rs12806698), RRM1 524T $>\mathrm{C}$ (11030918), CDA 79A $>\mathrm{C}$ (rs2072671), CDA $435 \mathrm{C}>\mathrm{T}$ (rs1048977) (details of the polymorphisms are shown in Table 1).

Table 1: Characteristic features, rs IDs and assay IDs of the studied polymorphisms.

\begin{tabular}{|llllll|}
\multirow{2}{*}{ Gene } & rs id & $\begin{array}{l}\text { Base pair } \\
\text { location/change }\end{array}$ & Gene location & SNP location & Assay ID \\
\hline \multirow{2}{*}{ RRM1 } & 12806698 & $-37 \mathrm{C}>\mathrm{A}$ & $11 \mathrm{p} 15.4$ & 5' UTR & C____2769831_10 \\
\cline { 2 - 6 } & 11030918 & $-524 \mathrm{~T}>\mathrm{C}$ & $11 \mathrm{p} 15.4$ & Upstream gene variant & C___2769829_10 \\
\hline \multirow{2}{*}{ CDA } & 2072671 & $79 \mathrm{~A}>\mathrm{C}$ & $1 \mathrm{p} 36.12$ & Synonymous variant & C___25472931_20 \\
\cline { 2 - 6 } & 1048977 & $-435 \mathrm{C}>\mathrm{T}$ & $1 \mathrm{p} 36.12$ & Missense variant & C__7477307_30 \\
\hline
\end{tabular}

Here, authors have established the distribution of the above variants involved in gemcitabine pharmacology in ethnic Asian population and their association with the susceptibility to lung cancer. We also aim to compare the similarities and/or dissimilarities between various 1000 genome populations such as AFR (African), AMR (American), EAS (East Asian), EUR (European), SAS (South Asian), BEB (Bengali in Bangladesh), GIH (Gujarati Indian in Houston, TX), ITU (Indian Telegu in the UK), PJL (Punjabi in Lahore, Pakistan), STU (Srilankan Tamil in the UK). 


\section{METHODS}

The clinical study was performed on 184 healthy participants with age ranging from 18 to 70 years. Unrelated healthy individuals resident of the Southern region of India for the successive 3 or more generations were included. The participants consisted of 95 males and 89 females, while the mean age was found to be 52.0 $( \pm 10.5)$ years. One hundred and twenty-three patients clinically determined to have lung cancer were recruited. Among them, 76 patients were males and 47 were female patients $53.5( \pm 9.9)$ (Table 2).

Table 2: Demographic characteristics of cases and controls.

\begin{tabular}{|lll|}
\hline Characteristic & Cases $(\mathbf{N}=\mathbf{1 2 3})$ & $\begin{array}{l}\text { Controls } \\
(\mathbf{N}=184)\end{array}$ \\
\hline Age (years) & $53.5 \pm 9.9$ & $52 \pm 10.5$ \\
\hline Male & $76(61.8)$ & $95(51.6)$ \\
\hline Female & $47(38.2)$ & $89(48.4)$ \\
\hline Smokers & $48(39.0)$ & $21(11.4)$ \\
\hline Alcohol & $23(18.7)$ & $31(16.8)$ \\
\hline Histology & & \\
\hline Adenocarcinoma & $90(73.1)$ & \\
\hline Adenosquamous & $4(3.3)$ & \\
\hline Squamous & $13(10.6)$ & \\
\hline Undifferentiated & $16(13.0)$ & \\
\hline ECOG & & \\
\hline (PS - 1) & $80(65.0)$ & \\
\hline (PS - 2) & $43(35.0)$ & \\
\hline EGFR Status & \\
\hline Positive & 18 \\
\hline Negative & 11 \\
\hline Unknown & 94 \\
\hline
\end{tabular}

ECOG-Eastern cooperative oncology group, PS - Performance status, EGFR-Epidermal growth factor receptor

Ethics committee permission was taken from the Institute Ethics Committee and also the written informed consent has been taken from all of the participants.

Venous blood $(5 \mathrm{~mL})$ was collected from each individual in test tubes with $100 \mu \mathrm{L}$ of $10 \%$ EDTA solution (ethylene diaminetetraacetic acid). DNA was obtained with the help of phenol-chloroform method. The separated DNA was stocked at $-20^{\circ} \mathrm{C}$ until genotyping was carried out. Four SNPs from two main genes which have been associated with metabolic pathway of gemcitabine (RRM1 -37C>A, RRM1 -524T >C, CDA 79A $>C$ and CDA $-435 \mathrm{C}>\mathrm{T}$ were genotyped by RT-PCR (Real-time polymerase chain reaction) with TaqMan SNP genotyping assay (Table 1).

For all the wells of the optical reaction plate, $5 \mu \mathrm{L}, 0.25 \mu \mathrm{L}$, $2.5 \mu \mathrm{L}$ PCR master mix, genotyping assay and diluted DNA was added respectively and finally deionized water was added to make up the final volume to $10 \mu \mathrm{L}$. The instrument was set up at $50^{\circ} \mathrm{C}$ at first for a couple of minutes time followed by at $95^{\circ} \mathrm{C}$ for the following 10 minutes to initialize TaqMan polymerase activity. Subsequently, 40 cycles of denaturation $\left(92^{\circ} \mathrm{C}\right.$ for 15 seconds) together with annealing and extension $\left(60^{\circ} \mathrm{C}\right.$ for 1 minute) were employed for the amplification of the DNA template. The discrimination of the alleles was analyzed by the inbuilt 7300 sequence detection software program (SDS), version 1.4. For quality assessment, $10 \%$ of the extracts were reanalyzed.

Direct gene count approach was adapted to ascertain the genotype together with allele frequencies. HardyWeinberg equilibrium with chi-square test used to evaluate the observed and the expected frequencies. The variations between the study population and of the various ethnic populations' allele frequencies, along with case control evaluation were assessed employing chi-square test by GraphPad InStat 3and haplotype analysis was performed using haplo view software version 4.2.

\section{RESULTS}

The allele frequencies of the three studied SNPs were in Hardy-Weinberg equilibrium. The RRM1 -37C>A had C allele frequency of $68.8 \%$ and $\mathrm{A}$ allele frequency of $31.3 \%$. The heterozygous genotype CA was seen in $41.8 \%$ while the homozygous genotypes $\mathrm{CC}$ and AA were seen in $47.8 \%$ and $10.3 \%$, respectively. The allele frequencies were significantly different from those observed among the AFR, AMR and PJL. They were similar when compared to the other subpopulations mentioned in table 3. The frequencies of $\mathrm{T}(63.3 \%)$ and $\mathrm{C}$ alleles $(36.7 \%)$ of RRM1 $-524 \mathrm{~T}>\mathrm{C}$ were statistically significant from other populations. The genotype frequencies are TT-40.8\%, TC $-45.1 \%$ whereas $\mathrm{CC}$ it is $14.1 \%$. The allele frequencies are significantly different from AFR, AMR, EAS and among the South Asian subpopulation the frequencies are different from ITU and PJL similar when compared with BEB, GIH and STU populations (Table 3).

The genotype frequencies of AA, AC, and CC of CDA 79 $\mathrm{A}>\mathrm{C}$ were $58.2 \%, 34.8 \%$, and $7.1 \%$, respectively. The $\mathrm{A}$ allele frequency was calculated to be $75.5 \%$, and the $\mathrm{C}$ allele frequency was $24.5 \%$. The allele frequencies were found to be statistically divergent from AFR, AMR, EAS, and EUR. The allele and genotype frequencies are similar compared with all the South Asian subpopulations. The homozygous wild genotype of CDA C>T i.e. $\mathrm{CC}$ is found to be $61.4 \%$, the heterozygous is $33.2 \%$ and the homozygous variant genotype is $5.4 \%$. The allele frequencies, $\mathrm{C}$ and $\mathrm{T}$ are $78 \%$ and $22 \%$ respectively. The allele frequencies are statistically different when compared to few 1000 genome populations as shown in the table. (AFR, AMR, EUR and GIH) (Table 3).

There were no gender wise frequency differences observed as in the healthy population except for CDA $C>T$ with a pvalue of 0.03 . Case-control analysis showed that the genotypes of RRM1 gene are associated with the risk of development of lung cancer (Table 4). 
Table 3: Comparison of the genotype and allele frequencies of the studied polymorphisms with 1000 genome populations.

\begin{tabular}{|c|c|c|c|c|c|c|c|c|c|c|}
\hline \multirow{2}{*}{ Polymorphism } & \multirow{2}{*}{ SI } & \multirow{2}{*}{ AFR } & \multirow{2}{*}{ AMR } & \multirow{2}{*}{ EAS } & \multirow{2}{*}{ EUR } & \multicolumn{5}{|l|}{ SAS } \\
\hline & & & & & & BEB & GIH & ITU & PJL & STU \\
\hline $\mathrm{N}$ & 184 & 661 & 347 & 504 & 503 & 86 & 103 & 102 & 96 & 102 \\
\hline \multicolumn{11}{|l|}{ RRM1 C>A } \\
\hline $\mathrm{CC}$ & 47.8 & 93.3 & 60.5 & 50.4 & 51.5 & 41.9 & 42.7 & 35.3 & 34.4 & 44.1 \\
\hline $\mathrm{CA}$ & 41.8 & 6.4 & 34.9 & 39.9 & 40.4 & 48.8 & 42.7 & 53.9 & 51.0 & 46.1 \\
\hline AA & 10.3 & 0.3 & 4.6 & 9.7 & 8.2 & 9.3 & 14.6 & 10.8 & 14.6 & 9.8 \\
\hline $\mathrm{C}$ & 68.8 & 96.5 & 78.0 & 70.3 & 71.7 & 66.3 & 64.1 & 62.3 & 59.9 & 67.2 \\
\hline A & 31.3 & $3.5^{*}$ & $22.0 *$ & 29.7 & 28.3 & 33.7 & 35.9 & 37.7 & $40.1 *$ & 32.8 \\
\hline \multicolumn{11}{|l|}{ RRM1 T>C } \\
\hline TT & 40.8 & 64.1 & 55.3 & 48.2 & 44.1 & 33.7 & 33.0 & 27.5 & 22.9 & 38.2 \\
\hline $\mathrm{TC}$ & 45.1 & 32.1 & 38.3 & 42.1 & 44.1 & 53.5 & 44.7 & 53.9 & 55.2 & 50.0 \\
\hline $\mathrm{CC}$ & 14.1 & 3.8 & 6.3 & 9.7 & 11.7 & 12.8 & 22.3 & 18.6 & 21.9 & 11.8 \\
\hline $\mathrm{T}$ & 63.3 & 80.2 & 74.5 & 69.2 & 66.2 & 60.5 & 55.3 & 54.4 & 50.5 & 63.2 \\
\hline $\mathrm{C}$ & 36.7 & $19.8 *$ & $25.5^{*}$ & $30.8^{*}$ & 33.8 & 39.5 & 44.7 & $45.6^{*}$ & $49.5 *$ & 36.8 \\
\hline \multicolumn{11}{|l|}{$\mathrm{CDA} A>C$} \\
\hline AA & 58.2 & 86.8 & 46.7 & 76.8 & 46.5 & 68.6 & 56.3 & 59.8 & 53.1 & 62.7 \\
\hline $\mathrm{AC}$ & 34.8 & 12.9 & 45.5 & 22.0 & 44.1 & 27.9 & 37.9 & 32.4 & 39.6 & 32.4 \\
\hline $\mathrm{CC}$ & 7.1 & 0.3 & 7.8 & 1.2 & 9.3 & 3.5 & 5.8 & 7.8 & 7.3 & 4.9 \\
\hline A & 75.5 & 93.3 & 69.5 & 87.8 & 68.6 & 82.6 & 75.2 & 76.0 & 72.9 & 78.9 \\
\hline $\mathrm{C}$ & 24.5 & $6.7 *$ & $30.5^{*}$ & $12.2 *$ & $31.4 *$ & 17.4 & 24.8 & 24.0 & 27.1 & 21.1 \\
\hline \multicolumn{11}{|l|}{$\mathrm{CDA} C>\mathrm{T}$} \\
\hline $\mathrm{CC}$ & 61.4 & 39.5 & 46.1 & 57.7 & 46.7 & 60.5 & 48.5 & 49.0 & 51.0 & 50.0 \\
\hline $\mathrm{CT}$ & 33.2 & 45.2 & 44.4 & 35.7 & 41.9 & 37.2 & 41.7 & 45.1 & 44.8 & 43.2 \\
\hline $\mathrm{TT}$ & 5.4 & 15.3 & 9.5 & 6.5 & 11.3 & 2.3 & 9.7 & 5.9 & 4.2 & 6.9 \\
\hline $\mathrm{C}$ & 78.0 & 62.1 & 68.3 & 75.6 & 67.7 & 79.1 & 69.4 & 71.6 & 73.4 & 71.6 \\
\hline $\mathrm{T}$ & 22.0 & $37.9 *$ & $31.7 *$ & 24.4 & $32.3^{*}$ & 20.9 & $30.6^{*}$ & 28.4 & 26.6 & 28.4 \\
\hline
\end{tabular}

AFR- African, AMR- American, EAS- East Asian, EUR-European, SAS- South Asian, BEB- Bengali in Bangladesh, GIH- Gujarati Indian in Houston, TX, ITU-Indian Telugu in the UK, PJL- Punjabi in Lahore, Pakistan, STU-Srilankan Tamil in the UK. *p Value <0.05 considered significant

Table 4: Case control analysis of the genotypes of the studied polymorphisms.

\begin{tabular}{|c|c|c|c|c|c|c|}
\hline $\begin{array}{l}\text { RRM1 } \\
\text { rs12806698 C>A }\end{array}$ & $\begin{array}{l}\text { Cases } N \\
(\%) \\
(\mathrm{N}=123)\end{array}$ & $\begin{array}{l}\text { Controls } \mathbf{N} \\
(\%) \\
(\mathbf{N}=184)\end{array}$ & $\begin{array}{l}\text { p- } \\
\text { Value }\end{array}$ & $\begin{array}{l}\text { Odds ratio } \\
(95 \% \mathrm{CI})\end{array}$ & $\begin{array}{l}\text { p- } \\
\text { Value }\end{array}$ & $\begin{array}{l}\text { *Adjusted Odds ratio } \\
(95 \% \text { CI })\end{array}$ \\
\hline $\mathrm{CC}$ & $38(30.9)$ & $88(47.8)$ & & & & \\
\hline $\mathrm{CA}$ & $63(51.2)$ & $77(41.8)$ & 0.0128 & 1.895 (1.143 to 3.142$)$ & 0.017 & $2.801(1.201$ to 6.533$)$ \\
\hline AA & $22(17.9)$ & $19(10.3)$ & 0.0064 & $2.681(1.302$ to 5.522$)$ & 0.193 & $1.473(0.823$ to 2.637$)$ \\
\hline \multicolumn{7}{|l|}{$\begin{array}{l}\text { RRM1 } \\
\text { rs11030918 T>C }\end{array}$} \\
\hline TT & $32(26.0)$ & $75(40.8)$ & & & & \\
\hline $\mathrm{TC}$ & $64(52.0)$ & $83(45.1)$ & 0.0270 & $1.807(1.067$ to 3.061$)$ & 0.075 & $2.063(0.930$ to 4.579$)$ \\
\hline $\mathrm{CC}$ & $27(22.0)$ & $26(14.1)$ & 0.0094 & $2.434(1.234$ to 4.801$)$ & 0.440 & $1.269(0.693$ to 2.325$)$ \\
\hline \multicolumn{7}{|l|}{$\begin{array}{l}\text { CDA } \\
\text { rs2072671 A>C }\end{array}$} \\
\hline AA & $76(61.8)$ & $107(58.2)$ & & & & \\
\hline $\mathrm{AC}$ & $42(34.1)$ & $64(34.8)$ & 0.7505 & $0.9239(0.5672$ to 1.505$)$ & & \\
\hline $\mathrm{CC}$ & $5(4.1)$ & $13(7.1)$ & 0.2564 & $0.5415(0.1852$ to 1.583$)$ & & \\
\hline \multicolumn{7}{|l|}{$\begin{array}{l}\text { CDA } \\
\text { rs1048977 C>T }\end{array}$} \\
\hline $\mathrm{CC}$ & $79(64.2)$ & $113(61.4)$ & & & & \\
\hline $\mathrm{CT}$ & $41(33.3)$ & $61(33.2)$ & 0.8747 & 0.9614 (0.5894 to 1.568$)$ & & \\
\hline TT & $3(2.4)$ & $10(5.4)$ & 0.2507 & $0.4291(0.1144$ to 1.610$)$ & & \\
\hline
\end{tabular}

*Adjusted for age, gender and smoking status 
The SNPs of CDA gene have no significant results and thus are not associated with lung cancer risk. Haplotype analysis revealed a strong linkage disequilibrium between the 2 SNPs of RRM1 with D' Value of 0.95 (Figure 1) and showed significant association with lung cancer risk.

The SNPs of CDA gene showed weak linkage disequilibrium and no significant association. The haplotype frequencies generated are represented in Table 5 .

Square shows the pairwise LD relationship between two SNPs and the values inside the square denotes $\mathrm{D}$ ' value is 0.98 and 0.34 respectively for RRM1 and CDA genes.

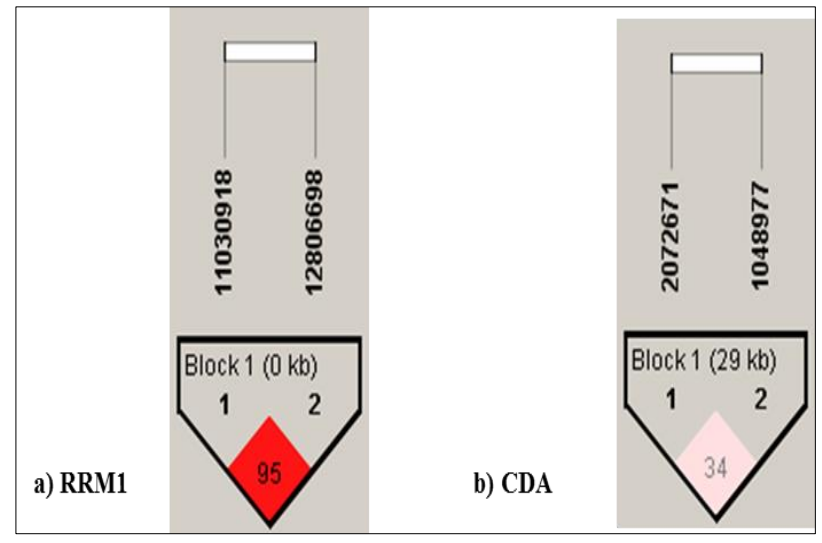

Figure 1: Linkage disequilibrium (LD) plot and Haplotype frequencies of RRM1 and CDA genes.

Table 5: Haplotypes association of RRM1 and CDA gene polymorphisms between cases and controls.

\begin{tabular}{|c|c|c|c|c|c|}
\hline \multirow{2}{*}{$\begin{array}{l}\text { RRM1 } \\
\text { rs11030918 T>C }\end{array}$} & \multirow{2}{*}{$\begin{array}{l}\text { RRM1 } \\
\text { rs12806698 C>A }\end{array}$} & \multirow{2}{*}{ Haplotypes } & \multicolumn{2}{|c|}{ Frequency of } & \multirow{2}{*}{ P value } \\
\hline & & & Cases & Controls & \\
\hline $\mathrm{T}$ & $\mathrm{C}$ & $\mathrm{TC}$ & 49.9 & 63.0 & 0.001 \\
\hline $\mathrm{C}$ & A & $\mathrm{CA}$ & 41.4 & 30.9 & 0.007 \\
\hline $\mathrm{C}$ & $\mathrm{C}$ & $\mathrm{CC}$ & 6.6 & 5.8 & 0.682 \\
\hline $\mathrm{T}$ & A & TA & 2.1 & 0.3 & 0.034 \\
\hline $\begin{array}{l}\mathrm{CDA} \\
\mathrm{rs} 2072671 \mathrm{~A}>\mathrm{C}\end{array}$ & $\begin{array}{l}\text { CDA } \\
\text { rs } 1048977 \mathrm{C}>\mathrm{T}\end{array}$ & & & & \\
\hline A & $\mathrm{C}$ & $\mathrm{AC}$ & 67.6 & 65.5 & 0.577 \\
\hline C & $\mathrm{C}$ & $\mathrm{CC}$ & 13.3 & 12.5 & 0.789 \\
\hline A & $\mathrm{T}$ & AT & 11.2 & 10.1 & 0.649 \\
\hline $\mathrm{C}$ & $\mathrm{T}$ & CT & 7.9 & 11.9 & 0.105 \\
\hline
\end{tabular}

\section{DISCUSSION}

The SNPs of candidate genes, which are involved in the transport, as well as metabolic pathway of gemcitabine based chemotherapy, such as CDA, dCK, SLC29A1, SLC29A3 and also the target molecule of gemcitabine, RRM1 have been ascertained to be associated with clinical outcomes in lung cancer patients. ${ }^{19-22}$ Ribonucleotide reductase M1 (RRM1) plays a crucial role in repairing the DNA damage. Gene expression studies have found that RRM1 can be used as a predictive marker in cancers treated using gemcitabine-based chemotherapy. ${ }^{23,24}$ Though few studies have found that the single nucleotide polymorphisms of RRM1 increased the susceptibility to gemcitabine therapy, there remains still a gap in finding out the actual influence on the response, toxicity with gemcitabine and risk of developing lung cancer. ${ }^{25,26}$

The studied SNPs showed significantly different results compared to the 1000 genome populations of AFR and AMR. In the subpopulation of south Asians, the results of RRM1 rs12806698 C>A were different only with PJL and are similar compared to the other subpopulations. In addition, RRM1 rs11030918 $\mathrm{T}>\mathrm{C}$ is significantly different from EAS and ITU subpopulation of South Asians. A retrospective analysis involving 97 South Korean patients exhibited differences in the genotype frequencies of both the studied SNPs of RRM1. Our study showed a higher percentage of heterozygous and the variant genotypes. ${ }^{27}$ The SNP rs11030918 T>C was found to be associated with the risk of developing lung cancer with dominant model of genetic analysis. In the present study, lung cancer risk was evident with the co-dominant model. Conversely, the other SNP rs 12806698 C>A showed no significant association as compared with the present study and Coskunpinar, et al. ${ }^{28,29}$ The genotype frequencies of RRM1 from a Chinese population-based study are comparable with healthy controls but the frequency of the mutant allele is found to be higher in this study. In addition, contradicting results found showing no association of the SNPs with susceptibility to lung cancer. $^{30}$ Nevertheless, gene expression studies confirmed that patients with lower levels of RRM1 have higher response rates and longer OS compared to the patients with high expression of RRM1 in both tissues as well as blood samples. ${ }^{31-33}$ 
Gemcitabine is eliminated after getting converted into its less potent form by the CDA enzyme. This enzyme plays a very important role in gemcitabine associated toxicity, as alteration in the levels or the activity leads to severe haematological toxicities. Many studies have confirmed the role of the CDA activity invitro and in vivo in the clinical outcomes of gemcitabine based chemotherapy.,34${ }^{37}$ In the present study, the genotype frequencies of CDA rs2072671 A>C are different from AFR, AMR, EAS and EUR; similar to all the subpopulations of South Asians. Another SNP CDA rs1048977 showed divergent results with AFR, AMR, EUR and the South Asian subpopulation GIH. The SNPs are not found to be associated with susceptibility to lung cancer and our results are in consistent with the literature found ${ }^{38}$ Our study found that the SNP, CDA rs2072671 A>C had higher wild type frequency when compared with Caucasian lung cancer patients. The authors also observed a significant association of this SNP with better response to gemcitabine. Conversely, a metaanalysis, reported that there was no significant impact of the above SNP on response to the drug, but found a correlation between homozygous wild type and the incidence of anemia. Presence of this SNP had reduced the incidence of developing anemia in patients on gemcitabine therapy. ${ }^{39,40}$ A pharmacokinetic based study to evaluate the impact of metabolic pathway genes of gemcitabine also showed that CDA rs1048977 C $>\mathrm{T}$ is associated with lower clearance of the inactive form leading to increased haematological toxicities. ${ }^{41}$ The variant genotype frequencies of CDA rs2072671 $\mathrm{A}>\mathrm{C}$ was high in European population whereas it was completely absent in Africans. With regard to CDA rs $1048977 \mathrm{C}>\mathrm{T}$, the frequencies are lower in Europeans and higher in African population as compared to the present study. Similar results were found in haplotype analysis with no linkage disequilibrium between the two SNPs. ${ }^{42}$

Different ethnic populations showed varied minor allele frequencies (MAF) of CDA rs2072671 but the MAFs of Korean, Japanese, Chinese-American and AfricanAmerican had lower frequencies and Caucasian-American had higher frequency compared to south Indian population which again brings in the role of ethnicities in evaluating the risk and outcomes in cancer patients. ${ }^{43}$ Similar results were found in two more studies, one of which is a North Indian population study. ${ }^{44,45}$ Although the minor allele frequency (MAF) was low, the patients who had heterozygous and homozygous mutant allele had a greater incidence of neutropenia compared to wild genotype. ${ }^{44}$ In contrast, CDA rs1048977 C>T was completely absent in a North Indian study with 50 healthy volunteers and also had a lower allele frequency of CDA rs2072671 A>C. ${ }^{45}$ This might be because of the less sample size that could not detect the variant allele. Another metanalysis with a pooled data from 13 studies had found that CDA rs2072671 $\mathrm{A}>\mathrm{C}$ is not associated with clinical outcomes of response and survival and that the patients who harbor variant allele may experience poor survival. In consistent with the available individual studies this metaanalysis also confirms the severe haematological toxicity associated with this SNP, thus suggesting the predictive value of CDA in cancer chemotherapy. ${ }^{46}$ Further studies are needed with larger sample size to confirm these results as some of them showed inverse correlation/association and also there is less literature available which actually may not be able to support the correlation of these reports.

\section{CONCLUSION}

The genotype and allele frequencies of SNPs of RRM1 and CDA are reported and are significantly different from 1000 genome population and other literatures. There was a strong linkage disequilibrium observed between the SNPs of RRM1. In addition, RRM1 being an important member of DNA damage repair pathway has been found to be associated with the susceptibility to lung cancer. These results may add to the available literature with predictive value in identifying individuals with high risk of developing lung cancer and also in guiding personalized treatment protocol for early detection of poor prognosis and toxicity by the genomic approach.

\section{ACKNOWLEDGEMENTS}

Authors would like to acknowledge JIPMER, Puducherry, India, for providing intramural research grant to carry out the study. They also acknowledge the patients and healthy volunteers who consented to participate in this study.

Funding: No funding sources

Conflict of interest: None declared

Ethical approval: The study was approved by the Institutional Ethics Committee (JIP/IEC/2014/4/310)

\section{REFERENCES}

1. Union for International Cancer Control. Agency for Research on Cancer. Globocan; 2008. Fast Stats. Available at: http://globocan.iarc.fr/Pages/fact_sheets_population.a spx. [Last accessed on 2018 August 3]

2. Pfister DG, Johnson DH, Azzoli CG, Sause W, Smith TJ, Baker Jr S, et al. American Society of Clinical Oncology Treatment of Unresectable Non-Small-Cell Lung Cancer Guideline: Update 2003. J Clin Oncol. 2004;22(2):330-53.

3. Toschi L, Finocchiaro G, Bartolini S, Gioia V, Cappuzzo F. Role of gemcitabine in cancer therapy. Future Oncol Lond Engl. 2005;1(1):7-17.

4. Metro G, Cappuzzo F, Finocchiaro G, Toschi L, Crinò L. Development of gemcitabine in non-small cell lung cancer: the Italian contribution. Ann Oncol Off J Eur Soc Med Oncol. 2006;17 Suppl 5:v37-46.

5. Zhang L, Gao G, Li X, Ren S, Li A, Xu J, et al. Association between Single Nucleotide Polymorphisms (SNPs) and Toxicity of Advanced Non-Small-Cell Lung Cancer Patients Treated with Chemotherapy. Perez-Gracia JL, editor. PLoS ONE. 2012;7(10):e48350. 
6. Burke W, Khoury MJ, Stewart A, Zimmern RL. The path from genome-based research to population health: development of an international public health genomics network. Genet Med. 2006;8(7):451-8.

7. $\mathrm{Ma} \mathrm{Q}, \mathrm{Lu}$ AYH. Pharmacogenetics, Pharmacogenomics, and Individualized Medicine. Pharmacol Rev. 2011;63(2):437-59.

8. Plunkett W, Huang $\mathrm{P}$, Searcy CE, Gandhi V. Gemcitabine: preclinical pharmacology and mechanisms of action. Semin Oncol. 1996;23(5 Suppl 10):3-15.

9. Joerger M, Burgers JA, Baas P, Doodeman VD, Smits PHM, Jansen RS, et al. Gene polymorphisms, pharmacokinetics, and hematological toxicity in advanced non-small-cell lung cancer patients receiving cisplatin/gemcitabine. Cancer Chemother Pharmacol. 2011;69(1):25-33.

10. Tibaldi C, Giovannetti E, Tiseo M, Leon LG, D'Incecco A, Loosekoot $\mathrm{N}$, et al. Correlation of cytidine deaminase polymorphisms and activity with clinical outcome in gemcitabine-/platinum-treated advanced non-small-cell lung cancer patients. Ann Oncol. 2011;23(3):670-7.

11. Soo RA, Wang LZ, Ng SS, Chong PY, Yong WP, Lee $\mathrm{SC}$, et al. Distribution of gemcitabine pathway genotypes in ethnic Asians and their association with outcome in non-small cell lung cancer patients. Lung Cancer. 2009;63(1):121-7.

12. Gong W, Zhang X, Wu J, Chen L, Li L, Sun J, et al. RRM1 expression and clinical outcome of gemcitabine-containing chemotherapy for advanced non-small-cell lung cancer: A meta-analysis. Lung Cancer. 2012;75(3):374-80.

13. Bepler G, Zheng Z, Gautam A, Sharma S, Cantor A, Sharma A, et al. Ribonucleotide reductase M1 gene promoter activity, polymorphisms, population frequencies, and clinical relevance. Lung Cancer. 2005;47(2):183-92.

14. West H, Lilenbaum R, Harpole D, Wozniak A, Sequist L. Molecular analysis-based treatment strategies for the management of non-small cell lung cancer. J Thorac Oncol Off Publ Int Assoc Study Lung Cancer. 2009;4(9 Suppl 2):S1029-1039-1042.

15. Obasaju CK, Ansari RH, Socinski MA, Chen R, Monberg MJ, Catalano RB, et al. A Comparison of white and African American outcomes from a threearm, randomized, phase III multicenter trial of advanced or metastatic non-small cell lung cancer. J Thorac Oncol Off Publ Int Assoc Study Lung Cancer. 2010;5(7):993-1000.

16. O'Donnell PH, Dolan ME. Cancer Pharmacoethnicity: Ethnic Differences in Susceptibility to the Effects of Chemotherapy. Clin Cancer Res. 2009;15(15):480614.

17. Tamang R, Singh L, Thangaraj K. Complex genetic origin of Indian populations and its implications. J Biosci. 2012;37(5):911-9.

18. Soo RA, Kawaguchi T, Loh M, Ou SHI, Shieh MP, Cho BC, et al. Differences in outcome and toxicity between Asian and caucasian patients with lung cancer treated with systemic therapy. Future Oncol. 2012;8(4):451-62.

19. Sugiyama E, Kaniwa N, Kim SR, Kikura-Hanajiri R, Hasegawa R, Maekawa K, et al. Pharmacokinetics of Gemcitabine in Japanese Cancer Patients: The Impact of a Cytidine Deaminase Polymorphism. J Clin Oncol. 2006;25(1):32-42.

20. Tanaka M, Javle M, Dong X, Eng C, Abbruzzese JL, Li D. Gemcitabine Metabolic and Transporter Gene Polymorphisms Are Associated with Drug Toxicity and Efficacy in Patients with Locally Advanced Pancreatic Cancer. Cancer. 2010;116(22):5325-35.

21. Soo RA, Wang LZ, Ng SS, Chong PY, Yong WP, Lee $\mathrm{SC}$, et al. Distribution of gemcitabine pathway genotypes in ethnic Asians and their association with outcome in non-small cell lung cancer patients. Lung Cancer. 2009;63(1):121-7.

22. Ceppi P, Volante M, Novello S, Rapa I, Danenberg KD, Danenberg PV, et al. ERCC1 and RRM1 gene expressions but not EGFR are predictive of shorter survival in advanced non-small-cell lung cancer treated with cisplatin and gemcitabine. Ann Oncol. 2006;17(12):1818-25.

23. Rosell R, Danenberg KD, Alberola V, Bepler G, Sanchez JJ, Camps C, et al. Ribonucleotide reductase messenger RNA expression and survival in gemcitabine/cisplatin-treated advanced non-small cell lung cancer patients. Clin Cancer Res Off J Am Assoc Cancer Res. 2004;10(4):1318-25.

24. Boukovinas I, Papadaki C, Mendez P, Taron M, Mavroudis D, Koutsopoulos A, et al. Tumor BRCA1, RRM1 and RRM2 mRNA Expression Levels and Clinical Response to First-Line Gemcitabine plus Docetaxel in Non-Small-Cell Lung Cancer Patients. PLOS ONE. 2008;3(11):e3695.

25. Rha SY, Jeung HC, Choi YH, Yang WI, Yoo JH, Kim $\mathrm{BS}$, et al. An association between RRM1 haplotype and gemcitabine-induced neutropenia in breast cancer patients. The Oncologist. 2007;12(6):622-30.

26. Dong S, Guo AL, Chen ZH, Wang Z, Zhang XC, Huang $Y$, et al. RRM1 single nucleotide polymorphism-37C $\rightarrow$ A correlates with progressionfree survival in NSCLC patients after gemcitabinebased chemotherapy. J Hematol Oncol J Hematol Oncol. 2010;3(1):10.

27. Kim SO, Jeong JY, Kim MR, Cho HJ, Ju JY, Kwon YS, et al. Efficacy of Gemcitabine in Patients with Non-Small Cell Lung Cancer According to Promoter Polymorphisms of the Ribonucleotide Reductase M1 Gene. Clin Cancer Res. 2008;14(10):3083-8.

28. $\mathrm{Xu} \mathrm{XL}$, Zheng J, Mao WM, Ling ZQ. RRM1 *151Aandgt;T, RRM1 -756Tandgt;C, and RRM1 585Tandgt;Gis associated with increased susceptibility of lung cancer in Chinese patients. Cancer Med. 2016;5(8):2084-90.

29. Coskunpinar E, Yildiz P, Aynaci E, Turna A, Musteri Oltulu Y, Hekimoglu E, et al. Investigation of some DNA repair genes association in non small cell lung cancer. Cell Mol Biol. 2015;61(8):57-62. 
30. Li X, Zhang J, Su C, Zhao X, Tang L, Zhou C. The association between polymorphisms in the DNA nucleotide excision repair genes and RRM1 gene and lung cancer risk. Thorac Cancer. 2012;3(3):239-48.

31. Zhang GB, Chen J, Wang LR, Li J, Li MW, Xu N, et al. RRM1 and ERCC1 expression in peripheral blood versus tumor tissue in gemcitabine/carboplatin-treated advanced non-small cell lung cancer. Cancer Chemother Pharmacol. 2012;69(5):1277-87.

32. Ulker M, Duman BB, Sahin B, Gumurdulu D. ERCC1 and RRM1 as a predictive parameter for non-small cell lung, ovarian or pancreas cancer treated with cisplatin and/or gemcitabine. Contemp Oncol (Pozn). 2015;3:207-13.

33. Rosell R, Felip E, Taron M, Majo J, Mendez P, Sanchez-Ronco $\mathrm{M}$, et al. Gene expression as a predictive marker of outcome in stage IIB-IIIA-IIIB non-small cell lung cancer after induction gemcitabine-based chemotherapy followed by resectional surgery. Clin Cancer Res Off J Am Assoc Cancer Res. 2004 ;10:4215s-4219s.

34. Dumontet C, Morschhauser F, Solal-Celigny P, Bouafia F, Bourgeois E, Thieblemont C, et al. Gemcitabine as a single agent in the treatment of relapsed or refractory low-grade non-Hodgkin's lymphoma. Br J Haematol. 2001;113(3):772-8.

35. McDonagh EM, Whirl-Carrillo M, Garten Y, Altman RB, Klein TE. From pharmacogenomic knowledge acquisition to clinical applications: the PharmGKB as a clinical pharmacogenomic biomarker resource. Biomark Med. 2011;5(6):795-806.

36. Mini E, Nobili S, Caciagli B, Landini I, Mazzei T. Cellular pharmacology of gemcitabine. Ann Oncol Off J Eur Soc Med Oncol. 2006;17 Suppl 5:v7-12.

37. Rosell R, Cobo M, Isla D, Camps C, Massuti B. Pharmacogenomics and gemcitabine. Ann Oncol. 2006;17(5):v13-6.

38. Zhou M, Wan HY, Gao BL, Ding YJ, Jun RX. Genetic polymorphisms of XPD and CDA and lung cancer risk. Oncol Lett. 2012;4(2):247-51.

39. Tibaldi C, Giovannetti E, Vasile E, Mey V, Laan AC, Nannizzi S, et al. Correlation of CDA, ERCC1, and XPD Polymorphisms with Response and Survival in
Gemcitabine/Cisplatin-Treated Advanced Non-Small Cell Lung Cancer Patients. Clin Cancer Res. 2008;14(6):1797-803.

40. Li H, Wang X, Wang X. The impact of CDA A79C gene polymorphisms on the response and hematologic toxicity in gemcitabine-treated patients: A metaanalysis. Int J Biol Markers. 2014;29(3):224-32.

41. Mitra AK, Kirstein MN, Khatri A, Skubitz KM, Dudek AZ, Greeno EW, et al. Pathway-based pharmacogenomics of gemcitabine pharmacokinetics in patients with solid tumors. Pharmacogenomics. 2012;13(9):1009-21.

42. Fukunaga AK, Marsh S, Murry DJ, Hurley TD, McLeod HL. Identification and analysis of singlenucleotide polymorphisms in the gemcitabine pharmacologic pathway. Pharmacogenomics J. 2004;4(5):307-14.

43. Sugiyama E, Lee SJ, Lee SS, Kim WY, Kim SR, Tohkin M, et al. Ethnic differences of two nonsynonymous single nucleotide polymorphisms in CDA gene. Drug Metab Pharmacokinet. 2009;24(6):553-6.

44. Xu J, Zhou Y, Zhang J, Chen Y, Zhuang R, Liu T, et al. High incidence of severe neutropenia after gemcitabine-based chemotherapy in Chinese cancer patients with CDA 79A $>$ C mutation. Clin Chim Acta. 2012;413(15-16):1284-7.

45. Iyer SN, Ankala A, Singhal RS, Hegde MR. Determination of common genetic variants in cytidine deaminase (CDA) gene in Indian ethnic population. Gene. 2013;524(1):35-9.

46. Ding X, Chen W, Fan H, Zhu B. Cytidine deaminase polymorphism predicts toxicity of gemcitabine-based chemotherapy. Gene. 2015;559(1):31-7.

Cite this article as: Tirumalasetty D, Shewade DG, Dubashi B, Katiboina SR. Ethnic differences in allele, genotype distributions and lung cancer risk of polymorphisms of gemcitabine metabolic pathway genes in south Indian population. Int J Basic Clin Pharmacol 2018;7:1693-700. 